\title{
ROZWÓJ SPOŁECZNO-EKONOMICZNY KRAJÓW PERYFERYJNYCH UNII EUROPEJSKIEJ
}

\section{WSTĘP}

Kraje Unii Europejskiej różnią się od siebie pod względem gospodarczym, społecznym, ustrojowo-politycznym czy środowiskowo-przyrodniczym. W burzliwych czasach rozbieżności są podkreślane częściej i głośniej niż podobieństwa, co sprawia wrażenie, że $\mathrm{w}$ ostatnich miesiącach w Europie na sile przybierają raczej procesy dezintegracji aniżeli integracji. Jednakże jeszcze w okresie wysokiej koniunktury mówiło się o istnieniu w ugrupowaniu dwóch klubów - krajów peryferyjnych i krajów bogatych, choć nierzadko nie precyzowano, na podstawie jakich kryteriów następuje ów podział. Celem niniejszego artykułu jest zbadanie poziomu rozwoju społeczno-ekonomicznego krajów, które w 2004 i w 2007 r. przystąpiły do UE (UE-12), na tle pozostałych krajów ugrupowania. Formułuje się przy tym hipotezę, że kraje dwóch ostatnich rozszerzeń należą do peryferii ugrupowania.

Artykuł składa się z czterech zasadniczych części. Rozpoczyna się rozważaniami na temat wielopłaszczyznowych różnic pomiędzy krajami tworzącymi UE, następnie w drugiej części zostaje zdefiniowane pojęcie obszaru peryferyjnego. W kolejnym etapie badań przedstawia się istotę rozwoju społeczno-ekonomicznego. W czwartej części dokonana zostaje analiza porównawcza krajów unijnych przy wykorzystaniu jednej z metod wielowymiarowej analizy porównawczej, co pozwala na osiągnięcie wyznaczonego celu i weryfikację postawionej hipotezy. 


\section{RÓŻNORODNOŚĆ JAKO PODSTAWOWA CECHA UNII EUROPEJSKIEJ}

Dewiza Unii Europejskiej In varietate concordia ${ }^{1} \mathrm{z}$ jednej strony wskazuje na leżącą u podstaw idei integracji jedność, a $z$ drugiej odwołuje się do będącej cechą charakterystyczną Starego Kontynentu różnorodności. Siła i zakres zróżnicowania w Europie jest wytworem sięgającej ponad 2,5 tys. lat wstecz cywilizacji europejskiej, jednak oddziaływanie „historycznych” czynników na zróżnicowania wewnętrzne współczesnej Europy słabnie ${ }^{2}$, a obecne sprzeczności interesów państw członkowskich UE wyrosły raczej na bazie różnic o naturze gospodarczej. Podziały w UE utrzymują się mimo długoletniości i zaawansowania procesu integracji, który jest związany z zachodzeniem w europejskiej społeczności procesów zorientowanych na łączenie elementów życia zbiorowego. Scalanie zachodzi dzięki istnieniu symbolicznej przestrzeni na kontynencie, przez którą wyraża się to, co uniwersalne, w stosunku do tego, co lokalne ${ }^{3}$. Zdążanie ku uniwersalności może sugerować, że powstałe ugrupowanie integracyjne jest tworem złożonym $z$ bardzo podobnych do siebie organizmów. W praktyce jednak efekty prób tworzenia czegoś uniwersalnego odbiegają od założeń, o czym świadczy między innymi używane przez teoretyków, praktyków gospodarczych i polityków hasło „Europa wielu prędkości”. Opiera się ono na przeświadczeniu, że w procesie integracji może dojść do wariacji w stopniu integracji prowadzonej przez państwa członkowskie. Wariacja ta może mieć dwa wymiary. W pierwszym $\mathrm{z}$ nich nie ma wspólnego punktu integracyjnego, ponieważ państwa mogą posiadać klauzule opcyjnie w tych dziedzinach polityki, których nie zaakceptują, co w konsekwencji prowadzi do Europy dwóch kręgów. Według drugiego wymiaru, państwa członkowskie prowadzą integrację w kierunku wspólnie akceptowanego ostatecznego punktu integracji, ale w różnym tempie ${ }^{4}$. Nierzadko hasło to odnosi się też do różnic w tempie wzrostu gospodarek. Rozbieżności między unijnymi krajami jest znacznie więcej i nie jest to niczym zdumiewającym, biorąc pod uwagę fakt, iż UE składa się aż z 27 krajów. Przykładowe podziały między nimi zostały przedstawione w tabeli 1 .

1 http://www.eurominority.eu/version/eng/languages-motto.asp (data dostępu: 19.09.2011).

2 A. Gałązka, Zróżnicowanie przestrzenne sytuacji spoteczno-gospodarczej na obszarze UE jako czynnik integracji i dezintegracji, [w:] K. Żukrowska (red.), Co dzieli, co integruje Wspólnotę Europejska?, Oficyna Wydawnicza Szkoła Główna Handlowa, Warszawa 2007, s. 167.

3 F. Gołembski, Kulturowe aspekty integracji europejskiej, Wydawnictwa Akademickie i Profesjonalne, Warszawa 2008, s. 202-203.

4 A. Konarzewska, Królestwo Danii, Królestwo Szwecji i Zjednoczone Królestwo Wielkiej Brytanii i Irlandii Pótnocnej a Unia Gospodarcza i Walutowa, Oficyna Wydawnicza Szkoła Główna Handlowa, Warszawa 2010, s. 46-47. 
Tabela. 1. Wybrane kryteria podziału Unii Europejskiej

\begin{tabular}{|c|c|c|c|}
\hline LP. & KRYTERIUM & GRUPY KRAJÓW/REGIONY & UwaGI \\
\hline 1 & Położenie krajów & $\begin{array}{l}\text { - centrum i peryferia, } \\
\text { - kraje zza „żelaznej kurtyny”i i pozostałe, } \\
\text { - Europa: Zachodnia, Północna, Południowo-Zachod- } \\
\text { nia, Środkowa, Wschodnia, Południowo-Wschodnia }\end{array}$ & $\begin{array}{l}\text { podane propozycje podziału krajów nie } \\
\text { są sprzeczne, ale komplementarne }\end{array}$ \\
\hline 2 & $\begin{array}{l}\text { Poziom dochodu } \\
\text { (na mieszkańca) }\end{array}$ & kraje wysoko rozwinięte i średnio rozwinięte & $\begin{array}{l}\text { wysoko rozwinięte - kraje o dochodzie } \\
\text { per capita powyżej średniej unijnej, } \\
\text { średnio rozwinięte - o dochodzie po- } \\
\text { niżej średniej unijnej }\end{array}$ \\
\hline 3 & $\begin{array}{l}\text { Poziom rozwoju } \\
\text { społeczno- } \\
\text {-gospodarczego }\end{array}$ & $\begin{array}{l}\text { kraje wysoko rozwinięte i średnio rozwinięte; przez } \\
\text { pojęcie zróżnicowania rozwojowego rozumie się } \\
\text { rozbieżności występujące między charakterystykami } \\
\text { dotyczącymi gospodarek krajów, które wywierają } \\
\text { wpływ na możliwości ich rozwoju i tworzenia warun- } \\
\text { ków dobrobytu obywateli }\end{array}$ & $\begin{array}{l}\text { dziedzinami stanowiącymi podstawy } \\
\text { do określenia wyróżików mogą być } \\
\text { np.: system gospodarczy, struktura go- } \\
\text { spodarki, warunki własności, wysokość } \\
\text { PKB i PKB per capita, instytucje i pra- } \\
\text { wodawstwo, powiązania gospodarki } \\
\text { z zagranicą, wysokość oszzzędności, } \\
\text { kapitał ludzki, sfera komunikowania } \\
\text { się }\end{array}$ \\
\hline 4 & $\begin{array}{l}\text { Rok przystąpienia } \\
\text { do EWG/UE }\end{array}$ & $\begin{array}{l}\text { państwa założycielskie oraz przystępujące w kolej- } \\
\text { nych latach do EWG/UE }\end{array}$ & $\begin{array}{l}\text { kolejne państwa przyjmowano w la- } \\
\text { tach: 1973, 1981, 1986, 1995, 2004, } \\
\text { 2007, więc można jeszcze dokonywá } \\
\text { innych podziałów }\end{array}$ \\
\hline 5 & $\begin{array}{l}\text { Uczestnictwo } \\
\text { w UGiW }\end{array}$ & $\begin{array}{l}\text { kraje, które przyjęły wspólną walutę i kraje pozosta- } \\
\text { jące poza strefą euro (w tym: kraje z derogacją - Eu- } \\
\text { ropa á la carte i kraje bez derogacji) }\end{array}$ & $\begin{array}{l}\text { każdą z tych grup można jeszcze po- } \\
\text { dzielić; w ramach pierwszej oddziela } \\
\text { się kraje peryferyjnestrefy euro (Grecja, } \\
\text { Hiszpania, Portugalia, Włochy, Irlandia } \\
\text { - PIIGS) od pozostałych, a w grupie } \\
\text { krajów bez derogacji - uczestniczące } \\
\text { w ERMIl i poza tym mechanizmem }\end{array}$ \\
\hline 6 & $\begin{array}{l}\text { Kręgi kulturowo- } \\
\text {-religijne }\end{array}$ & $\begin{array}{l}\text { krąg zachodnioeuropejski/północnoamerykański/ } \\
\text { /transatlantycki, krąg skandynawsko/celtycko/anglo- } \\
\text { saski, krąg rzymsko/karolińsko/galijski, krąg grecko- } \\
\text {-bizantyjsko/prawosławny, krąg iberyjsko/islamski/ } \\
\text { /północnoafrykański }\end{array}$ & $\begin{array}{l}\text { poszczególne kręgi mają wymiar } \\
\text { ponadnarodowy i przenikają się wza- } \\
\text { jemnie }\end{array}$ \\
\hline 7 & $\begin{array}{l}\text { Ponadnarodowe } \\
\text { obszary językowe }\end{array}$ & $\begin{array}{l}\text { obszary, w ramach których włada się językami } \\
\text { określanymi jako: bałtyckie, celtyckie, germańskie, } \\
\text { romańskie, słowiańskie, ugrofińskie, inne }\end{array}$ & $\begin{array}{l}\text { języków podawanych przez mieszkań- } \\
\text { ców UE jako ojczysty jest 16, w tym } \\
\text { grupa języków mniejszościowych. }\end{array}$ \\
\hline
\end{tabular}

Źródło: opracowanie własne na podstawie: K. Żukrowska, Zróżnicowanie rozwojowe jako warunek pokonywania opóźnień rozwojowych, [w:] K. Żukrowska (red.), Zróżnicowanie rozwoju jako impuls prowzrostowy w gospodarce światowej, SGH, Warszawa 2008, s. 17-18; B. Lisocka-Jaegermann, Unia Europejska - przestrzeń, kultura, tożsamość, [w:] J. Makowski (red.), Geografia Unii Europejskiej, PWN, Warszawa 2008, s. 176 i 180, http://www.eurominority.eu/version/eng/languages1.asp (data dostępu: 19.09.2011). 
Wskazany w powyższej tabeli zestaw kryteriów z pewnością nie wyczerpuje kwestii funkcjonujących wewnątrz UE podziałów. Istniejące różnice mają odmienne etiologie oraz niejednakowy wpływ (kierunek i siłę) na procesy integracyjne. $Z$ punktu widzenia celu opracowania największe znaczenie mają różnice dotyczące poziomu rozwoju społeczno-gospodarczego krajów oraz położenia geograficznego. Kryteria te często mogą, a nawet powinny być rozpatrywane razem, czego dowodzi treść kolejnego podrozdziału.

\section{PERYFERIA - ISTOTA POJĘCIA I SPECYFIKA PERYFERYJNOŚCI W EUROPIE}

W tabeli 1 pojęciami centrów i peryferii posłużono się w odniesieniu do krajów UE, jednak pierwotnie terminy te powstały na określenie osiowego podziału pracy w ramach gospodarki światowej w latach 50 . XX wieku i zostały spopularyzowane przez R. Prebischa oraz Komisję Gospodarczą ds. Ameryki Łacińskiej przy ONZ ${ }^{5}$. Współcześnie słowo „peryferyjność” jest używane w różnych kontekstach przez przedstawicieli wielu nurtów teoretycznych, przy czym zawsze wiąże się ono z pojęciem dystansu, odmienności czy asymetrii. W zależności od punktu odniesienia dany obszar bywa postrzegany zarówno jako centralny, jak i peryferyjny. Ponadto, region może przejawiać cechy peryferyjności w określonej dziedzinie, a równocześnie stanowić centrum $w$ innej ${ }^{6}$. $Z$ tych powodów, definiując obszar peryferyjny, autorzy często posługują się jednocześnie pojęciem obszaru centralnego. Tak jest między innymi w analizie systemowej, gdzie określenie centrum-peryferie ma charakter relacyjny, a nie jest wyłącznie parą terminów zreifikowanych, czyli mających swoje odrębne, ustalone znaczenia ${ }^{7}$. Podobne podejście widoczne jest w dorobku twórców nowych teorii wymiany. Na przykład, według przedstawicieli nowej geografii ekonomicznej, centrami są terytorialnie zorganizowane podsystemy społeczeństwa, w których koncentruje się działalność gospodarcza, oraz odznaczające się wysoką zdolnością generowania innowacji. $Z$ kolei peryferie to regiony poza centrami, których rozwój jest determinowany przez ich zależność od rdzeni ${ }^{8}$. Peryferie nie muszą być izolowane barierami administracyjnymi od krajów centrum, ale charakteryzuje je asymetria związków ekonomicznych z tymi

5 K. Krzysztofek, M. S. Szczepański, Zrozumieć rozwój. Od spoteczeństw tradycyjnych do informacyjnych, Wydawnictwo Uniwersytetu Śląskiego, Katowice 2005, s. 101-102. s. $55-56$

A. Olechnicka, Regiony peryferyjne w gospodarce informacyjnej, Scholar, Warszawa 2004,

7 I. Wallerstein, Analiza systemów-światów. Wprowadzenie, Wydawnictwo Akademickie Dialog, Warszawa 2007, s. 34 oraz 129-130.

8 R. Domański, Zasady geografii spoteczno-ekonomicznej, PWN, Warszawa 1993, s. 165. 
krajami oraz niższy poziom dochodu na mieszkańca ${ }^{9}$. Peryferyjność może mieć zatem wymiar geograficzny, wynikający $z$ dystansu wyrażonego w jednostkach odległości, a także ekonomiczny, związany z dystansem rozwojowym. Te dwa wymiary nie wykluczają się, a wręcz przeciwnie - niekorzystne położenie geograficzne determinuje niższy poziom rozwoju, niekorzystna lokalizacja utrudnia bowiem handel, współpracę $\mathrm{B}+\mathrm{R}$, transport czy przepływ ludności. W praktyce występuje również sytuacja przeciwna - kiedy kraj, pomimo relatywnie korzystnego położenia geograficznego, bywa zaliczany do peryferii właśnie $z$ uwagi na niższy poziom rozwoju i asymetrię związków z innymi krajami.

Wydaje się, że podobna do ostatniej tendencja ma miejsce w UE. Kraje, które przystąpiły do ugrupowania w 2004 (UE-10) oraz 2007 r. (Bułgaria i Rumunia) intuicyjnie są zaliczane do peryferii, choć wpływ czynnika geograficznego na takie postrzeganie jest dyskusyjny. Część UE-12 faktycznie jest położona na obrzeżach UE, ale stwierdzenie to pozostaje prawdziwe również dla niektórych krajów Piętnastki ${ }^{10}$. Większe znaczenie w podziale UE na centrum i peryferie ma więc obecność innych czynników. Przed 2004 r. pomysł akcesji biedniejszych krajów budził jedne $\mathrm{z}$ najgorętszych dyskusji w historii integracji europejskiej. Państwa członkowskie zgadzały się, że poszerzenie na wschód to właściwy krok, bo służy powiększeniu obszaru dobrobytu i bezpieczeństwa, ale odnosiły się do tego z umiarkowanym entuzjazmem. Wątpliwości były na tyle duże, iż w debacie publicznej regularnie pojawiał się wątek „zmęczenia rozszerzaniem”"11. Społeczeństwa Europy Zachodniej mogły też obawiać się wynikających z transformacji ustrojowej słabości, jakie wykazywały kraje Europy Środkowo-Wschodniej (m.in. wycofanie państwa $z$ wielu dziedzin życia społecznego i wcześniejszej aktywności na polu polityk gospodarczych). Innym ważnym symptomem słabości nowych krajów członkowskich była szczupłość zasobów potrzebnych do budowania innowacyjnej gospodarki ${ }^{12}$. Nie bez znaczenia pozostawało przywiązanie społeczeństw do starego systemu, które wpływa na kulturę, sposób myślenia, mentalność, wartości. Powiększenie UE z 2004 r., według niektórych autorów i polityków, przyczyniło się do fiaska prób realizacji zadań Strategii Lizbońskiej, gdyż przyjęcie biedniejszych członków pogłębiło lukę dochodową między mieszkańcami Unii a mieszkańcami USA ${ }^{13}$. Dane statystyczne potwierdzają, że akcesja do Unii 10 państw

9 P. Krugman, Geography and Trade, Leuven University Press, Leuven and MIT Press Cambridge, London 1991, s. 92-99.

10 Na przykład dla Szwecji i Finlandii, a nie są określane mianem peryferii.

11 J. Pinder, S. Usherwood, Unia Europejska, PWE, Warszawa 2009, s. 137.

12 T. G. Grosse, Innowacyjna gospodarka na peryferiach?, Instytut Spraw Publicznych, Warszawa 2007, s. 30-31.

13 F. Breuss, G. Fink, P. Haiss, How well prepared are the New Member States for the European Monetary Union?, „Journal of Policy Modeling” 2004, no. 26, s. 771. 
w 2004 r. znacznie powiększyła różnice regionalne - około 92\% populacji nowych krajów członkowskich zamieszkiwało regiony, w których PKB per capita wynosił poniżej średniej UE-25, a 66\% żyło w obszarach, gdzie był on niższy niż 50\% średniej. Różnice pogłębiły się jeszcze bardziej po przystąpieniu Bułgarii i Rumunii ${ }^{14}$. Nawet jeśli próbuje się unikać porównania z Luksemburgiem, który pod względem dochodu na mieszkańca góruje nad UE, w większości przypadków dochód przypadający na Europejczyka ze „starej”Unii znacznie przekraczał dochód na głowę mieszkańca nowych państw, choć i w gronie UE-15 znalazły się kraje, których wynik nie osiągnął pułapu średniej unijnej - to Portugalia i Grecja (już w 2004 r. ich dochód był niższy niż Cypru). Pomiędzy 2004 a 2010 r. gospodarki UE rozwijały się w zróżnicowanym tempie. W większości przypadków szybciej rosły gospodarki o niższym w 2004 r. dochodzie na mieszkańca niż te najbogatsze. Niemały wpływ na kraje Piętnastki wywarł kryzys gospodarczy, większość z nich (Belgia, Dania, Irlandia, Grecja, Francja, Włochy, Austria, Szwecja, Wielka Brytania) odnotowała spadek dochodu. W przypadku pozostałych krajów wzrost był słaby lub w ogóle nie wystąpił. Dzięki temu, w porównaniu z 2004 r., luka dochodowa pomiędzy krajami rozszerzeń z lat 2004 i 2007 a „starą” Unią uległa redukcji, choć nadal pozostaje znacząca. Zmiany w latach 2004-2010 nie pozwoliły na dogonienie przez UE-12 krajów wysoko rozwiniętych, ani nawet na osiągnięcie średniej dla UE-2715.

Mimo upływu lat, akcentuje się rozszerzenia UE z 2004 oraz z 2007 r. o „inne” niż „stara” Unia kraje. W wielu opracowaniach nadal oddziela się UE-10, a wraz z nimi Bułgarię i Rumunię, od „bogatej” Piętnastki. „Nowe” kraje UE są postrzegane jako peryferie krajów wysoko rozwiniętych, mimo tego, że sama Piętnastka nie jest jednolitą grupą. Nie sposób także - nawiązując do definicji obszarów peryferyjnych i centralnych - uznać wszystkie kraje UE-15 za liderów innowacji. Warto sprawdzić, czy luka dochodowa idzie w parze z szerzej rozumianą luką rozwojową. Najpierw jednak konieczne jest doprecyzowanie, jak rozumiany jest rozwój społeczno-ekonomiczny.

\section{ROZWÓJ SPOŁECZNO-EKONOMICZNY - ISTOTA POJĘCIA I DYLEMATY POMIARU}

Rozwój społeczno-ekonomiczny jest pojmowany bardzo szeroko. Oprócz czynników ilościowych uwzględnia elementy jakościowe, przemiany strukturalne

14 http://ec.europa.eu/regional_policy/sources/docoffic/official/reports/cohesion3/cohesion3_ pl.htm (data dostępu: 3.07.2011).

$15 \mathrm{http}: / /$ epp.eurostat.ec.europa.eu/tgm/table.do?tab=table\&init=1\&plugin=1\&language=en \&pcode=tsieb010 (data dostępu: 15.07.2011). 
w gospodarce, polityce, kulturze, systemie instytucjonalnym, środowisku przyrodniczym i technice. Charakteryzuje się dążeniem do osiągnięcia równowagi ekonomicznej, społecznej, ekologicznej i technologicznej przez realizację założonych zadań za pomocą odpowiednich narzędzi ${ }^{16}$. Już w tabeli 1, definiując zróżnicowanie rozwojowe, wskazano przykładowe obszary, w których rozwój może być badany. $Z$ tabeli oraz przytoczonej powyżej definicji można wysnuć dwa wnioski. Po pierwsze, rozwój społeczno-gospodarczy jest pojęciem względnym, co oznacza, że wyznaczniki rozwoju danego kraju muszą być przedstawiane w relacji do wartości charakteryzujących inny kraj (lub kraje). Po drugie, rozwój jest związany z dążeniem do poprawy sytuacji gospodarczej, z pozytywną zmianą. Unika się przy tym sformułowania, że jest dążeniem do określonego stanu, bo to sugerowałoby ujęcie statyczne, a po osiągnięciu pożądanego poziomu zazwyczaj stawiane są kolejne wyzwania $^{17}$. Kierunek dążenia zależy od poziomu rozwoju społeczno-ekonomicznego - peryferie aspirują, by osiągnąć poziom reprezentowany przez gospodarki wiodące, te drugie natomiast kreślą swoje odrębne cele. Dodatkowo, kraje ugrupowania integracyjnego zwykle wytyczają wspólną płaszczyznę odniesienia i formułują strategię rozwojową, która ma przyczynić się do ich upodobnienia. Proces upodabniania krajów jest określany mianem konwergencji.

Konwergencji mogą podlegać zarówno zmienne nominalne, jak i realne odpowiednio wyróżnia się konwergencję nominalną i realną. Ta pierwsza jest rozumiana wąsko, na przykład jako dążenie do wypełnienia kryteriów z Maastricht lub zbieżność kosztów, cen i związanych z tymi kategoriami wskaźników. Konwergencja realna oznacza trwałe zmiany strukturalne, konwergencję warunków pracy czy poziomów życia. Konwegencja realna wykazywana jest więc najczęściej $\mathrm{w}$ analizach empirycznych, konwergencja nominalna wiąże się zaś z ujęciami instytucjonalnymi ${ }^{18}$. Niniejszym zwraca się uwagę na konwergencję realną oznaczającą zbieżność zmiennych odpowiedzialnych za rozwój społeczno-ekonomiczny. Bardzo skrupulatni w definiowaniu zbliżonych pod względem zakresu pojęć są W. Baumol, R. Nelson i E. Wolf - odróżniają aż 7 terminów i zjawisk związanych z konwergencją realną. Wśród powiązanych ze sobą pojęć autorzy wymieniają następujące: homogenizacja (homogenization), doganianie (catching-up), całkowita konwergencja (gross convergence), statystycznie objaśniana konwergencja (expla-

16 Por. M. G. Woźniak, Wzrost gospodarczy. Podstawy teoretyczne, Wydawnictwo Uniwersytetu Ekonomicznego w Krakowie, Kraków 2008, s. 20-32, oraz S. Pangsy-Kania, Polityka innowacyjna państwa a narodowa strategia konkurencyjnego rozwoju, Wydawnictwo Uniwersytetu Gdańskiego, Gdańsk 2007, s. 83.

17 J. Pajestka, Czynniki i wspótzależności rozwoju spoteczno-gospodarczego. Determinanty postępu, PWE, Warszawa 1981, s. 21-22.

18 J. Kudełko, A. Prusek, K. Zieliński, Europejska polityka spójności oraz jej efekty w Polsce, Wydawnictwo Uniwersytetu Ekonomicznego w Krakowie, Kraków 2011, s. 27; J. Wolszczak-Derlacz, Wspólna Europa, różne ceny - analiza procesów konwergencji, CeDeWu, Warszawa 2007, s. 10. 
ined convergence), szczątkowa konwergencja (residual convergence), asymptotycznie doskonała konwergencja (asymptotically perfect convergence), graniczna konwergencja (bounded convergence). Zostały one omówione w tabeli 2.

Tabela 2. Rodzaje konwergencji

\begin{tabular}{|c|l|l|}
\hline LP. & \multicolumn{1}{|c|}{ PoJ̨̧cIE } & \multicolumn{1}{c|}{ Isтota } \\
\hline 1 & Homogenizacja & $\begin{array}{l}\text { redukcja dyspersji pomiędzy grupą krajów (lub regionów czy przemysłów) w odniesieniu } \\
\text { do wybranej miary wyników działalności }\end{array}$ \\
\hline 2 & Doganianie & $\begin{array}{l}\text { zawężanie luki pomiędzy wynikami kraju wiodącego a wynikami pozostałych krajów pod } \\
\text { względem różnych czynników }\end{array}$ \\
\hline 3 & Całkowita konwergencja & jednoczesne zachodzenie zarówno homogenizacji, jak i doganiania \\
\hline 5 & $\begin{array}{l}\text { Statystycznie objaśniana } \\
\text { konwergencja }\end{array}$ & $\begin{array}{l}\text { odnosi się do oceny roli mierzalnych zmiennych, które wpływają na czas i stopień konwer- } \\
\text { gencji zachodzącej między gospodarkami (np. wpływ wydatków na edukację) }\end{array}$ \\
\hline 6 & $\begin{array}{l}\text { Asymptotycznie doskonała } \\
\text { konwergencja }\end{array}$ & $\begin{array}{l}\text { występuje w sytuacji, kiedy po zidentyfikowaniu i oszacowaniu czynników odpowiedzial- } \\
\text { nych za konwergencję (patrz powyżej) pozostają statystycznie niewyjaśnione czynniki } \\
\text { decydujące o konwergencji }\end{array}$ \\
\hline 7 & $\begin{array}{l}\text { Graniczna konwergencja } \\
\text { wskaźników makroekonomicznych, np. dochód per capita }\end{array}$ & $\begin{array}{l}\text { występuje, kiedy odpowiednie zmienne dotyczące dwóch krajów zmierzają do jakiegośs } \\
\text { docelowego poziomu w różnym tempie, ale domniemywa się, że ostatecznie będzie to } \\
\text { poziom zbliżony }\end{array}$ \\
\hline
\end{tabular}

Źródło: W. J. Baumol, R. R. Nelson, E. N. Wolf, The Convergence of Productivity, Its Significance, and Its Varied Connotations, [w:] W. J. Baumol, R. R. Nelson, E. N. Wolf (ed.), Convergence of Productivity. Cross-National Studies and Historical Evidence, Oxford University Press 1994, s. 6-11.

Niektóre definiowane pojęcia są bardzo wąskie i powinny być odnoszone tylko do wzrostu gospodarczego, część z nich pozostawia jednak pewien margines na interpretację badacza w zakresie wyznaczników rozwoju. Posługując się powyższą terminologią, peryferie rozwijają się w sposób doganiający, uwzględniając zaś kraje peryferie i kraje centrum, rozwój odnosi się do całkowitej konwergencji. Doganianie jest więc warunkiem koniecznym konwergencji.

Gdyby rozwój sprowadzać do kategorii wzrostu gospodarczego, wówczas wiodący byłby kraj o najwyższej produktywności lub poziomie PKB per capita. Jak jednak zaznaczono, rozwój społeczno-gospodarczy pojmuje się szeroko i w związku z tym podaje się wątpliwość, czy można wskazać kraj wiodący we wszystkich aspektach rozwoju. Nieco żartobliwie, ale trafiając w sedno, A. Giddens pisze, że Europa stanowiąca silną konkurencję w świecie miałaby: fiński poziom upowszechnienia ICT, niemiecką wartość produktywności przemysłowej, szwedzki poziom równości, duński poziom zatrudnienia, irlandzki wzrost gospodarczy, włoską kuchnię w połączeniu $\mathrm{z}$ węgierskim winem (pitym w umiarkowanych 
ilościach), czeski poziom kultury literackiej, francuski poziom opieki zdrowotnej, luksemburską wartość PKB na mieszkańca, norweski poziom wykształcenia, brytyjski kosmopolityzm, cypryjską pogodę ${ }^{19}$. Socjolog wskazuje cechy idealnej według niego gospodarki. Zestaw cech jest oczywiście dyskusyjny, ale sama myśl oddaje sens koncepcji granicy cywilizacyjnej, czyli wzorcowego obiektu, do którego kraje powinny dążyć. W przypadku, gdyby jakiś kraj notował najwyższe świadczące o poziomie rozwoju wskaźniki, byłby przykładem osiągnięcia takiej granicy, ale w praktyce wydaje się to niemożliwe. Zatem, pisząc o całkowitej konwergencji cech decydujących o rozwoju społeczno-ekonomicznym, odnosi się to do upodabniania gospodarek do abstrakcyjnej granicy cywilizacyjnej.

Próbując sprawdzić, czy kraje opisane jako peryferie (o dochodzie na mieszkańca niższym niż średnia dla UE-27) zasługują na to określenie również w kontekście poziomu rozwoju społeczno-ekonomicznego, należy porównać je z tzw. gospodarkami centrum pod względem poziomu wartości zmiennych decydujących o rozwoju. Pozwoli to ocenić, jak daleko od granicy cywilizacyjnej znajdują się wszystkie gospodarki.

\section{POMIAR ROZWOJU SPOŁECZNO-EKONOMICZNEGO KRAJÓW UE}

W trosce o obiektywny dobór zmiennych zostały one wytypowane nie na podstawie Giddensowskiej wizji idealnej Europy, ale na bazie aktualnie obowiązującej strategii rozwojowej UE, która nosi nazwę Europa 2020. Trzy sformułowane $\mathrm{w}$ ramach Strategii priorytety to: wzrost inteligentny (zwiększenie roli wiedzy, innowacji, edukacji i społeczeństwa cyfrowego), wzrost zrównoważony (produkcja efektywniej wykorzystująca zasoby przy jednoczesnym zwiększeniu konkurencyjności) oraz wzrost sprzyjający włączeniu społecznemu (zwiększenie aktywności zawodowej, podnoszenie kwalifikacji i walka z ubóstwem). Dotyczą one zatem obszarów nakreślonych w przyjętej definicji rozwoju społeczno-ekonomicznego (gospodarka, społeczeństwo, ekologia i technologie). Co ważne z punktu widzenia celu artykułu, twórcy Strategii zakładają, iż nie jest to podejście polegające na „mierzeniu wszystkich jedną miarą”, ale program dla wszystkich państw członkowskich, uwzględniający ich różne potrzeby czy pozycje startowe. Cele są istotne dla wszystkich państw członkowskich, bez względu na ich staż w Unii i różnice $\mathrm{w}$ poziomie życia. Sformułowane priorytety są reprezentatywne, przy czym ich lista nie jest wyczerpująca, a kraje mogą wyznaczać sobie dodatkowe cele ${ }^{20}$.

19 A. Giddens, Europa w epoce globalnej, PWN, Warszawa 2009, s. 46-47.

20 KOMUNIKAT KOMISJI EUROPA 2020 Strategia na rzecz inteligentnego i zrównoważonego rozwoju sprzyjającego włączeniu społecznemu, Bruksela, 3.3.2010, KOM(2010) 2020 wersja ostateczna. http://ec.europa.eu/eu2020/pdf/1_PL_ACT_part1_v1.pdf (data dostępu: 15.07.2011). 
Metodą badawczą, którą wybrano, by ocenić potencjalne różnice rozwojowe między krajami UE, jest porządkowanie liniowe metodą wzorcową autorstwa Z. Hellwiga. Polega ono na ustaleniu kolejności obiektów (gospodarek) ze względu na wartości więcej niż jednej cechy od „najlepszego” do „najgorszego”. $\mathrm{Na}$ podstawie maksymalnych wartości zmiennych diagnostycznych w badanej zbiorowości tworzy się tzw. obiekt wzorcowy, a następnie wyznacza odległość poszczególnych obiektów od wzorca rozwoju. Rosnąca wartość miary syntetycznej świadczy o zbliżaniu się do wzorca rozwoju ${ }^{21}$. Obiektem wzorcowym jest abstrakcyjna granica cywilizacyjna, czyli odległości od wzorca rozwoju to nic innego, jak dystans dzielący gospodarkę od granicy cywilizacyjnej. Zanim jednak uporządkuje się gospodarki w rankingu, trzeba przejść kilka etapów badania.

$\mathrm{Na}$ początku należy wybrać zmienne i określić ich charakter. Kryterium podziału jest sposób oddziaływania każdej zmiennej na stopień rozwoju. Jeżeli większe wartości danej cechy pozwalają zakwalifikować obiekt jako lepszy zgodnie z kryterium ogólnym, to cecha taka nazywana jest stymulantą, natomiast gdy większe wartości cechy implikują gorszą ocenę obiektu w świetle kryterium ogólnego, mówi się o destymulancie ${ }^{22}$. Jak wspomniano, zmienne dobrano na podstawie Strategii Europa 2020 (tabela 3).

Tabela 3. Wykaz zmiennych uwzględnionych w badaniu

\begin{tabular}{|c|c|c|}
\hline ZMienNA & JEDNOSTKA MIARY & Stymulanta/deEstymulanta (S/D) \\
\hline Wydatki na B + R (GERD) & $\%$ PKB & $S$ \\
\hline $\begin{array}{l}\text { Osoby przedwcześnie } \\
\text { kończące naukę szkolną }\end{array}$ & \% liczby osób w wieku 18-24 & D \\
\hline Wyższe wykształcenie & \% liczby osób w wieku 30-34 & $\mathrm{s}$ \\
\hline Emisja gazów cieplarnianych $\left(\mathrm{CO}_{2}\right)$ & kilogram & D \\
\hline $\begin{array}{l}\text { Udział elektryczności z odnawialnej energii } \\
\text { w konsumpcji elektryczności brutto }\end{array}$ & \% konsumpcji elektryczności & $S$ \\
\hline Intensywność energetyczna gospodarki & $\begin{array}{l}\mathrm{kg} \text { odpowiednika ropy naftowej na } \\
1000 \text { euro }\end{array}$ & D \\
\hline Stopa zatrudnienia & \% liczby osób w wieku 20-64 & $\mathrm{s}$ \\
\hline
\end{tabular}

21 W. Pluta, Wielowymiarowa analiza porównawcza w badaniach ekonomicznych. Metody taksonomiczne i analizy czynnikowej, PWE, Warszawa 1977, s. 20.

22 Ponadto istnieją cechy, które mają określone najbardziej pożądane wartości, a odchylenia w dół i w górę są oceniane jako niepożądane z punktu widzenia kryterium ogólnego (nominanty). Zob. J. Pociecha, B. Podolec, A. Sokołowski, K. Zając, Metody taksonomiczne w badaniach spoteczno-ekonomicznych, PWE, Warszawa 1988, s. 67. 
Ciąg dalszy tabeli 3

\begin{tabular}{|c|c|c|}
\hline ZmienNa & JEDNOSTKA MIARY & Stymulanta/destymulanta (S/D) \\
\hline Zagrożenie ubóstwem bądź wykluczeniem & \% populacji & D \\
\hline $\begin{array}{l}\text { Zamieszkujący w gospodarstwach } \\
\text { domowych charakteryzujących się } \\
\text { niską aktywnością na rynku pracy }\end{array}$ & \% populacji w wieku 0-59 & D \\
\hline $\begin{array}{l}\text { Stopa ludności żyjącej w ryzyku biedy } \\
\text { po transferach socjalnych }\end{array}$ & \% populacji & D \\
\hline Odsetek żyjących w złych warunkach & \% populacji & D \\
\hline
\end{tabular}

Źródło: opracowanie własne na podstawie danych Eurostat http://epp.eurostat.ec.europa.eu/portal/page/ portal/europe_2020_indicators/headline_indicators (15.09.2011).

Wśród zmiennych diagnostycznych występują zarówno stymulanty, jak i destymulanty, należy zatem sprowadzić je do jednorodności ze względu na charakter ich związku z kryterium ogólnym. W tym celu przekształca się destymulanty w stymulanty według przekształcenia ilorazowego, co można wyrazić wzorem 1.

$$
x_{i j}^{S}=b\left[x_{i j}^{D}\right]^{-1} \text { dla } i=1,2, \ldots n ; j=1,2, \ldots, \mathrm{m} ; \mathrm{b}>0,
$$

gdzie: $x_{i j}^{D}$ - wartość $j$-tej zmiennej destymulanty w i-tym obiekcie, $x_{i j}^{S}$ - wartość $j$-tej zmiennej po przekształceniu w stymulantę $\mathrm{w} i$-tym obiekcie, $\mathrm{b}$ - stała przyjmowana w sposób arbitralny, najczęściej $b=1^{23}$.

Zmienne wyrażone są w odmiennych jednostkach miary, ponadto mają różne obszary zmienności, nie stanowiąc zestawu porównywalnych danych. W celu eliminacji wymienionych ograniczeń zmienne poddaje się standaryzacji zgodnie $\mathrm{z}$ formułą 2 .

$$
z_{i j}=\frac{x_{i j}-\bar{x}_{j}}{s\left(x_{j}\right)} \quad i=1,2, \ldots, \mathrm{n} ; \mathrm{j}=1,2, \ldots, \mathrm{m}
$$

gdzie: $\bar{x}_{j}=\frac{1}{n} \sum_{i=1}^{n} x_{i j} ; s_{j}=\sqrt{\sum_{i=1}^{n}\left(x_{i j}-\overline{x_{l \jmath}}\right)^{2}}$.

23 T. Panek, Statystyczne metody wielowymiarowej analizy porównawczej, Szkoła Główna Handlowa, Warszawa 2009, s. 36. 
Stosowanie w sposób bezpośredni cech uwolnionych od miana do wyznaczenia wartości miar podobieństwa oznacza przyjęcie założenia o przypisywaniu im jednakowego znaczenia dla opisu obiektów, a tym samym o jednakowych wagach poszczególnych zmiennych ${ }^{24}$. W dalszej kolejności konstruuje się wzorcową jednostkę obserwacji. Wartości zmiennych są wyznaczone w taki sposób, że dla przekształconych stymulant przyjmuje się wartość maksymalną zmiennej. Kolejny etap to obliczenie odległości poszczególnych jednostek obserwacji od wzorca rozwoju. Odległość poszczególnych obiektów od wzorca wyznacza się według formuły odległości euklidesowej (wzór 3).

$$
d_{i 0}=\sqrt{\sum_{j=1}^{m}\left(x_{i j}-x_{0 j}\right)^{2}}
$$

W końcu następuje obliczenie syntetycznej miary rozwoju $\left(\mathrm{SMR}_{\mathrm{i}}\right) \mathrm{SMR}_{\mathrm{i}}$ jest funkcją określoną na zmiennych i wyznaczoną dla każdego obiektu ze zbioru zgodnie $\mathrm{z}$ formułą:

$$
S M R_{i}=1-\frac{d_{0 i}}{d_{0}}
$$

gdzie: $d_{0}=\bar{d}_{0}+2 S_{0}$,

gdzie: $\bar{d}_{0}=\frac{1}{n} \sum_{i=1}^{n} d_{0 i} ; S_{0}=\sqrt{\frac{1}{n} \sum_{i=1}^{n}\left(d_{0 i}-\bar{d}_{0}\right)^{2}}$

Skonstruowany miernik rozwoju jest wielkością syntetyczną, która zastępuje opis gospodarek przy użyciu zbioru cech diagnostycznych opisem za pomocą jednej agregatowej wielkości ${ }^{25}$. Przyjmuje on wartości ze zbioru [0;1]. Na podstawie tego miernika budowany jest ranking krajów Unii Europejskiej. W tabeli 4 zamieszczono wyniki dokonanych obliczeń w kolejności od największej do najmniejszej wartości syntetycznego miernika rozwoju.

24 Przyjęcie jednakowych wag zmiennych nie zawsze jest uzasadnione. Poszczególnym cechom diagnostycznym można przypisać różne wagi, stanowi to decyzję badacza podejmowaną na przykład na podstawie opinii ekspertów. Zob. J. Pociecha, B. Podolec, A. Sokołowski, K. Zając, op. cit., s. 66.

25 Aplikacyjne wartości tych mierników są duże, ponieważ umożliwiają numeryczny opis jakościowych zjawisk społeczno-ekonomicznych, których nie można bezpośrednio zmierzyć, oraz umożliwiają konstruowanie globalnych wskaźników opartych na cechach diagnostycznych wyrażonych w naturalnych jednostkach miary. Dzięki temu unika się problemów związanych z przyjmowaniem określonego systemu cen, a w przypadku porównań międzynarodowych - problemów wynikających z różnych jednostek pieniężnych; E. Nowak, Metody taksonomiczne w klasyfikacji obiektów spoteczno-gospodarczych, PWE, Warszawa 1990, s. 85. 
Tabela 4. Ranking krajów Unii Europejskiej ze względu na wartość syntetycznego miernika rozwoju SMR

\begin{tabular}{|c|c|c|}
\hline Miessce W Rankingu & Kraj & SMRI \\
\hline 1. & Szwecja & 0,557291 \\
\hline 2. & Dania & 0,433674 \\
\hline 3. & Finlandia & 0,416262 \\
\hline 4. & Austria & 0,399789 \\
\hline 5. & Luksemburg & 0,388286 \\
\hline 6. & Holandia & 0,387843 \\
\hline 7. & Słowenia & 0,378893 \\
\hline 8. & Czechy & 0,334054 \\
\hline 9. & Francja & 0,315692 \\
\hline 10. & Niemcy & 0,282622 \\
\hline 11. & Estonia & 0,271322 \\
\hline 12. & Słowacja & 0,259052 \\
\hline 13. & Wielka Brytania & 0,235074 \\
\hline 14. & Belgia & 0,220243 \\
\hline 15. & Cypr & 0,209478 \\
\hline 16. & Litwa & 0,204805 \\
\hline 17. & Portugalia & 0,198401 \\
\hline 18. & Polska & 0,186708 \\
\hline 19. & Hiszpania & 0,178282 \\
\hline 20. & Irlandia & 0,157026 \\
\hline 21. & Grecja & 0,135961 \\
\hline 22. & Węgry & 0,125353 \\
\hline 23. & Łotwa & 0,123333 \\
\hline 24. & Włochy & 0,121104 \\
\hline 25. & Bułgaria & 0,082332 \\
\hline 26. & Malta & 0,080122 \\
\hline 27. & Rumunia & 0,069038 \\
\hline
\end{tabular}

Źródło: obliczenia własne na podstawie danych statystycznych z bazy Eurostat z 2010 roku. 
Miejsce w rankingu świadczy o tym, jak daleko gospodarka znajduje się od współczesnej granicy cywilizacyjnej. Wyniki zaprezentowane w powyższej tabeli mogą w dużym stopniu zaskakiwać, ponieważ w pierwszej dziesiątce i tuż za nią znalazły się kraje rozszerzenia z 2004 r. Na czele rankingu znalazły się państwa skandynawskie, a po nich kolejne trzy kraje Piętnastki. Już na kolejnych miejscach znalazły się Słowenia i Czechy. Relatywnie wysoka, 8 pozycja południowego sąsiada Polski jest imponująca, jeśli podkreślić, że Czechy znalazły się w zestawieniu przed Francją i Niemcami. Estonii i Słowacji (odpowiednio 11. i 12. miejsce) udało się natomiast wyprzedzić między innymi Wielką Brytanię i Belgię. Oznacza to, że niektóre kraje postrzegane jako peryferyjne cechuje mniejszy dystans do granicy cywilizacyjnej, a tym samym wyższy poziom rozwoju społeczno-gospodarczego niż wiele krajów traktowanych jako centrum. Miejsca od 15. w dół rankingu zajęły kraje dwóch ostatnich rozszerzeń oraz „problematyczne” kraje strefy euro (tzw. PIIGS - Portugalia, Irlandia, Grecja, Hiszpania, Włochy). Polska znalazła się na 18. miejscu. Można zadać sobie pytanie, czy satysfakcjonujące jest to, że wyprzedziła Irlandię, Grecję, Hiszpanię, a nawet Włochy. Te ostatnie wypadły z całej UE-15 najsłabiej, ranking zamykają zaś: Bułgaria, Malta i Rumunia, czyli ich odległość od granicy cywilizacyjnej jest największa.

Okazuje się więc, iż po uwzględnieniu zmiennych świadczących o poziomie rozwoju społeczno-ekonomicznego pozycja niektórych krajów o wysokim poziomie dochodu na mieszkańca jest gorsza niż krajów o niższym poziomie dochodu per capita.

\section{ZAKOŃCZENIE}

Kraje dwóch ostatnich rozszerzeń Unii Europejskiej są intuicyjnie określane jako peryferie ugrupowania, co wynika z poziomu dochodu na mieszkańca, ale w pewnym stopniu także $\mathrm{z}$ położenia geograficznego oraz dziedzictwa kulturowego wcześniejszego systemu gospodarczego. Również w statystykach międzynarodowych przyjął się podział ugrupowania na UE-15 oraz kraje rozszerzeń z 2004 i 2007 r. (UE-12). Celowość jego utrwalania tylko częściowo znajduje potwierdzenie w wartościach PKB per capita poszczególnych krajów. Wprawdzie wszystkie kraje UE-12 mają dochód niższy niż średnia UE-27, jednak nie wszystkie kraje UE-15 mają wyższy niż średni poziom dochodu, co dyskwalifikuje ich przynależność do klubu krajów centrum. Słuszność funkcjonującego zwyczajowo podziału na centrum i peryferia nie znajduje tym bardziej potwierdzenia w wartościach syntetycznego wskaźnika rozwoju krajów UE. Można zatem obalić hipotezę, iż cała grupa UE-12 tworzy klub krajów peryferyjnych. Wiele z nich cechuje się wyższym poziomem rozwoju społeczno-ekonomicznego niż niektóre 
kraje Piętnastki. Dyskusyjne jest oczywiście to, jaka wartość $\mathrm{SMR}_{\mathrm{i}}$ stanowi granicę między krajami centrum a krajami peryferyjnymi. Aby jednak zweryfikować hipotezę, nie jest konieczne rozstrzyganie tego dylematu. Wystarczy rozważyć pierwszą i ostatnią dziesiątkę rankingu (tabela 4), by dostrzec, że w obu znalazły się zarówno kraje UE-15, jak i UE-12.

Wyznaczone wartości syntetycznych mierników rozwoju sugerują, że rozpiętości w poziomie rozwoju społeczno-ekonomicznego między krajami unijnymi są relatywnie duże. Refleksji należy poddać pytanie, w jakim stopniu negatywnie wpływają one na rozwój UE jako całości oraz postrzeganie tego ugrupowania na świecie.

\section{BIBLIOGRAFIA}

Baumol W. J., Nelson R. R., Wolf E. N., The Convergence of Productivity, Its Significance, and Its Varied Connotations, [w:] W. J. Baumol, R. R. Nelson, E. N. Wolf (ed.), Convergence of Productivity. Cross-National Studies and Historical Evidence, Oxford University Press 1994.

Breuss F., Fink G., Haiss P., How well prepared are the New Member States for the European Monetary Union?, „Journal of Policy Modeling” 2004, no. 26.

Domański R., Zasady geografii spoteczno-ekonomicznej, PWN, Warszawa 1993.

Gałązka A., Zróżnicowanie przestrzenne sytuacji społeczno-gospodarczej na obszarze UE jako czynnik integracji i dezintegracji, [w:] K. Żukrowska (red.), Co dzieli, co integruje Wspólnotę Europejska?, SGH, Warszawa 2007.

Giddens A., Europa w epoce globalnej, PWN, Warszawa 2009.

Gołembski F., Kulturowe aspekty integracji europejskiej, Wydawnictwa Akademickie i Profesjonalne, Warszawa 2008.

Grosse T. G., Innowacyjna gospodarka na peryferiach?, Instytut Spraw Publicznych, Warszawa 2007.

KOMUNIKAT KOMISJI EUROPA 2020 Strategia na rzecz inteligentnego i zrównoważonego rozwoju sprzyjającego włączeniu społecznemu, Bruksela, 3.3.2010, KOM(2010) 2020 wersja ostateczna. http://ec.europa.eu/eu2020/pdf/1_PL_ACT_ part1_v1.pdf (data dostępu: 15.07.2011).

Konarzewska A., Królestwo Danii, Królestwo Szwecji i Zjednoczone Królestwo Wielkiej Brytanii i Irlandii Pótnocnej a Unia Gospodarcza i Walutowa, Oficyna Wydawnicza Szkoła Główna Handlowa, Warszawa 2010.

Krugman P., Geography and Trade, Leuven University Press, Leuven and MIT Press Cambridge, London 1991.

Krzysztofek K., Szczepański M. S., Zrozumieć rozwój. Od spoteczeństw tradycyjnych do informacyjnych, Wydawnictwo Uniwersytetu Śląskiego, Katowice 2005.

Kudełko J., Prusek A., Zieliński K., Europejska polityka spójności oraz jej efekty w Polsce, Wydawnictwo Uniwersytetu Ekonomicznego w Krakowie, Kraków 2011. 
Lisocka-Jaegermann B., Unia Europejska - przestrzeń, kultura, tożsamość, [w:] J. Makowski (red.), Geografia Unii Europejskiej, PWN, Warszawa 2008.

Nowak E., Metody taksonomiczne w klasyfikacji obiektów spoteczno-gospodarczych, PWE, Warszawa 1990.

Olechnicka A., Regiony peryferyjne w gospodarce informacyjnej, Scholar, Warszawa 2004.

Pajestka J., Czynniki i wspótzależności rozwoju spoteczno-gospodarczego. Determinanty postępu, PWE, Warszawa 1981.

Panek T., Statystyczne metody wielowymiarowej analizy porównawczej, Szkoła Główna Handlowa, Warszawa 2009.

Pangsy-Kania S., Polityka innowacyjna pañstwa a narodowa strategia konkurencyjnego rozwoju, Wydawnictwo Uniwersytetu Gdańskiego, Gdańsk 2007.

Pinder J., Usherwood S., Unia Europejska, PWE, Warszawa 2009.

Pluta W., Wielowymiarowa analiza porównawcza w badaniach ekonomicznych. Metody taksonomiczne i analizy czynnikowej, PWE, Warszawa 1977.

Pociecha J., Podolec B., Sokołowski A., Zając K., Metody taksonomiczne w badaniach spoteczno-ekonomicznych, PWE, Warszawa 1988.

Wallerstein I., Analiza systemów-światów. Wprowadzenie, Wydawnictwo Akademickie Dialog, Warszawa 2007.

Wolszczak-Derlacz J., Wspólna Europa, różne ceny - analiza procesów konwergencji, CeDeWu, Warszawa 2007.

Woźniak M. G., Wzrost gospodarczy. Podstawy teoretyczne, Wydawnictwo Uniwersytetu Ekonomicznego w Krakowie, Kraków 2008.

Żukrowska K., Zróżnicowanie rozwojowe jako warunek pokonywania opóznień rozwojowych, [w:] K. Żukrowska (red.), Zróżnicowanie rozwoju jako impuls prowzrostowy w gospodarce światowej, SGH, Warszawa 2008.

http://www.eurominority.eu/version/eng/languages-motto.asp (data dostępu: 19.09.2011). http://ec.europa.eu/regional_policy/sources/docoffic/official/reports/cohesion3/cohesion3_pl.htm (data dostępu: 3.07.2011).

http://epp.eurostat.ec.europa.eu/tgm/table.do?tab=table\&init=1\&plugin=1\&language=e n\&pcode=tsieb010 (data dostępu: 15.07.2011).

http://epp.eurostat.ec.europa.eu/portal/page/portal/europe_2020_indicators/headline_ indicators (data dostępu: 15.09.2011).

\section{STRESZCZENIE}

Kraje należące do Unii Europejskiej różnią się pod wieloma względami, w tym położeniem geograficznym oraz poziomem rozwoju. Kryteria te są powiązane, co skutkuje istnieniem w powszechnej opinii dwóch klubów - krajów centrum oraz krajów peryferyjnych. Niniejszy artykuł rozważa różnie interpretowaną koncepcję peryferyjności oraz pojęcie rozwoju społeczno-ekonomicznego. Proces rozwoju krajów UE powinien skutkować upodabnianiem się gospodarek i zbliżaniem ich do granicy cywilizacyjnej. Przeprowadzone badania empiryczne wskazują jednak, że kraje rozwijają się w zróżnicowanym tempie. 


\section{SOCIO-ECONOMIC DEVELOPMENT OF EUROPEAN UNION'S PERIPHERY}

\section{SUMMARY}

One of the basic features of the European Union is the existence of a distance between countries - literally, in geographical sense and implicitly - the development gap. The second, especially, is the subject of this deliberation. In the theoretical part of this paper the basic idea of peripherality and the sense of socio-economic development are explained. There is surely some causation running from peripherality to low income, however, there is a strong indication that the main causation runs the other way. All the countries which belong to the European Union theoretically should converge, but the pace of this process is varied. In consequence, some economies are quite near to the frontiers of civilisation and some of them are stragglers. The presented empirical study concerns the level of socio-economic development of analyzed countries. 
